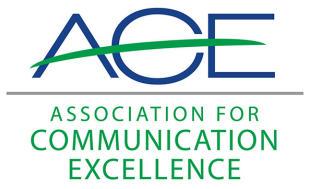

Journal of Applied Communications

\title{
Space Requirements for Justified Versus Unjustified Columns; Technical Writing Style: Attitudes Toward Scientists and Their Writing; The Use and Effectiveness of Paid Promotion for Extension Education Programs
}

\author{
Fred Berggren \\ LaRae H. Wales \\ Marguerite G. Ashman
}

See next page for additional authors

Follow this and additional works at: https://newprairiepress.org/jac cc) (i) (2)

This work is licensed under a Creative Commons Attribution-Noncommercial-Share Alike 4.0 License.

\section{Recommended Citation}

Berggren, Fred; Wales, LaRae H.; Ashman, Marguerite G.; Aleong, John; and Scherer, Chris (1979) "Space Requirements for Justified Versus Unjustified Columns; Technical Writing Style: Attitudes Toward Scientists and Their Writing; The Use and Effectiveness of Paid Promotion for Extension Education Programs," Journal of Applied Communications: Vol. 62: Iss. 3. https://doi.org/10.4148/1051-0834.1875

This Research Brief is brought to you for free and open access by New Prairie Press. It has been accepted for inclusion in Journal of Applied Communications by an authorized administrator of New Prairie Press. For more information, please contact cads@k-state.edu. 
Space Requirements for Justified Versus Unjustified Columns; Technical Writing Style: Attitudes Toward Scientists and Their Writing; The Use and Effectiveness of Paid Promotion for Extension Education Programs

\author{
Abstract \\ Three research briefs: Space Requirements for Justified Versus Unjustified Columns; Technical Writing \\ Style: Attitudes Toward Scientists and Their Writing; The Use and Effectiveness of Paid Promotion for \\ Extension Education Programs
}

Authors

Fred Berggren, LaRae H. Wales, Marguerite G. Ashman, John Aleong, and Chris Scherer 

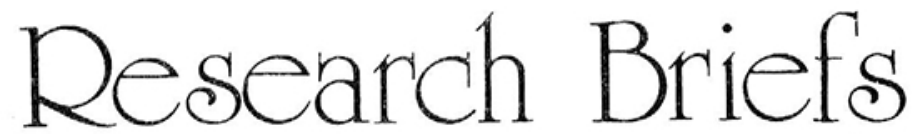

Includes explanations of practical communication, training media methods, and equipment use (1-2 typed pages). Send briefs to Robert Hays or James F. Evans, Office of Agricultural Communications, College of Agriculture, University of Illinois, Urbana, IL 61801.

\section{Space Requirements for Justified Versus Unjustified Columns}

"Ragged right" type composition-columns with unjustified right-hand margins-may be highly desirable for aesthetic reasons. This printing format, however, may require up to 10 percent more space or paper.

Three periodicals containing material in this format were sampled: Tennessee Cooperator, New York's Food and Life Sciences Quarterly, and Parade magazine. Numbers of lines sampled were 108, 121, and 74, respectively. Last lines of pragraphs were excluded, along with short lines around paragraph heads.

With jutified margins, the lines in the respective publications would have totaled 1,512 picas, 1,694 picas, and 1,733 picas. Actual line lengths in the "ragged right" format totaled $1,392,1,534$, and 1,600 picas, respectively. This represents "lost" space of 8.6, 10.4, and 8.1 percent.

In other typesetting samples, fuller use of space may be achieved while still retaining the unjustified right margins. However, for the periodical facing a continued paper shortage or extremely high paper costs, flush-right printing may prove more efficient.

Fred Berggren, University of Tennessee

\section{Technical Writing Style: Attitudes Toward Scientists and Their Writing}

Editors at the Vermont Experiment Station conducted a study of technical writing style in an effort to 
find what writing style is preferred and how style influences readers' attitudes toward the authors.

Questionnaires including passages from two similar articles on the hormonal basis of aggression in animals were submitted to 1,645 scientists and 24 editors from 12 Northeast experiment stations and 69 journal editors from across North America.

One passage, supposedly written by a Mr. Smith, was of "standard reading ease." The second, by Mr. Brown, was "very difficult to read." Half the questionnaires presented the Brown version first and half the Smith version first. After reading the two passages, respondents were asked questions about readability and about their feelings of esteem for the two authors. (This part of the questionnaire was developed by Ewa Bardell of the Institute of Science and Technology at the University of Wales, Cardiff.)

The first hypothesis was that, given a choice, station scientists would prefer manuscripts written in a style less complicated and more direct than that frequently found in scientific journals. This proved to be the case. Sixty-six percent of the scientists preferred the Smith style. Of those who read the complicated Brown passage first and found a difference between the two passages, about 90 percent preferred the Smith style. Of those who read the Smith passage first, about 54 percent preferred the Smith style.

The second hypothesis was that factors other than readability influence attitudes toward writing style and authors. Study results were ambiguous. But responses broken down by order of presentation showed some interesting patterns.

Those who read the more complicated Brown version first selected the Smith version as being far more readable and held author Smith in much greater esteem than did the group as a whole or those who read the Smith version first. It was assumed this was because the respondents probably had struggled through the more complicated Brown version and therefore were very receptive to the simpler Smith version.

Those who read the Smith version first also preferred it and rated it as being more readable than the

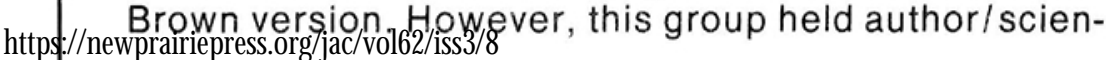


tist Brown in greater esteem than Smith. Ovbiously something other than readability influenced these results.

The Brown style resembles that frequently found in technical journals today and is considered appropriate by many in the academic and scientific communities. Those who read the less complicated Smith version first were somewhat familiar with the subject matter and therefore probably had less trouble with the Brown passage than did those who read it first. As a result, they probably looked more favorably upon author/scientist Brown who wrote in a style they are used to.

This study seems to indicate that experiment station editors can feel confident they are giving the scientific community what it wants when they apply the same principles of readability to station manuscripts that are used with Extension manuscripts (keeping in mind, of course, that the audiences are different). However, they must be sensitive to the fact that some scientists hold in high esteem authors who use a more traditional but less readable style of writing.

LaRae H. Wales, Marguerite G. Ashman, and John Aleong, Vermont Agricultural Experiment Station

\section{The Use and Effectiveness of Paid Promotion for Extension Education Programs}

In recent years the University of Illinois Cooperative Extension Service has used paid newspaper display advertisements to promote training programs for persons who prepare income tax returns. Results were mixed. This study was designed to evaluate paid promotion for Extension education programs.

Sixteen counties were selected in which to test paid ads. Counties were classified according to previous use or non-use of such ads and response levels in those where ads had been used.

Camera-ready ads were prepared, including the address and phone number of the respective county 
Extension office. Two different ads were placed, each to run only once. The first promoted a workshop for beginning tax preparers, the second the Illinois Farm Income Tax School for advanced professionals. Both ads included a clip-out coupon. Careful response records were kept.

The 44 ads placed in 22 selected newspapers at a total cost of $\$ 2,288.55$ elicited 217 responses. This represented a per-response cost of $\$ 10.55$. Sixty known enrollments resulted, bringing the cost per enrollee to $\$ 38.14$. Most of these paid an enrollment fee of $\$ 35$.

For metropolitan counties (popultion 100,000 or more) the per-response cost was $\$ 7.45$ and the cost per student enrolled dropped to $\$ 26.37$. In rural counties of less than 50,000 population the cost per response was $\$ 18.47$ and the cost per student who enrolled was $\$ 73.91$.

All participants in the program were given a questionnaire on how they learned of it. About 16 percent said they remembered seeing the paid newspaper ad, although only 1.4 percent reported first learning about the program through the ad. (Among the advanced group, most had participated in previous years and received direct mail information on the program.)

Questionnaire response showed that 75 percent of those enrolled in the advanced school and 42 percent in the beginners' workshop recalled having learned of the program through direct mail, either a promotional flyer or an Extension newletter. Thirty-nine percent of the beginners and 13.6 percent of the advanced students said they learned of it through friends or employers.

Newspaper articles also ranked higher than advertisements as a source, cited by 31 percent of the beginners and 8 percent of the advanced students. Magazines, radio, and television were cited by relatively few participants as their source of information, all below 5 percent.

These findings suggest that paid newspaper display advertising is considerably less effective in promoting Extension education programs than personal referral and direct mail and somewhat less effective than newspaper articles.

They suggest that display advertising may be more https://newprairiepress.org/jac/vol62/iss3/8 
promising in metropolitan areas where Extension's traditional forms of promotion, such as regularly scheduled radio programs or newspaper columns, are less visible. They indicate that paid advertising is less effective in rural areas.

Cost of the ads was not justified if increased enrollment is the only objective. However, if additional longterm benefits such as increased enrollment in other programs or general awareness of Extension education opportunities could be assessed, the cost effectiveness might be greater than measured by this study.

Chris Scherer, University of Illinois 
Journal of Applied Communications, Vol. 62, Iss. 3 [1979], Art. 8

https://newprairiepress.org/jac/vol62/iss3/8

DOI: 10.4148/1051-0834.1875 